\title{
Role of Interleukin-6, Gamma Interferon and Adenosine Deaminase Markers in Management of Pleural Effusion Patients
}

\author{
MAM Marie ${ }^{1}$, J John $^{2 *}$, L Gowda Krishnappa ${ }^{1 *}$, S Gopalkrishnan³ ${ }^{3}$ SR Bindurani ${ }^{4}$, P CS ${ }^{1}$
}

\begin{abstract}
Objective: Pleural effusion is a common diagnostic and clinical problem. Neoplasms and tuberculosis are the most frequent diagnostic causes of such effusions. Conventional laboratory methods for diagnosis of such effusion are inefficient because tubercle bacilli are rarely seen in direct examinations of pleural fluid. The present study evaluates interleukin-6 (IL-6), gamma interferon (IFN- $\gamma$ ) and adenosine deaminase (ADA) as diagnostic tools in pleural effusion.

Methods: Interleukin-6, IFN- $\gamma$ and ADA were measured in pleural fluid from the patients, with exudative pleural effusion from tuberculous, malignant and postpneumonic origin and transudative pleural effusion of systemic origin in order to evaluate the diagnostic utility of these.

Results: The three markers were detectable in all effusions with significantly high levels in exudative as compared to transudative effusions. There was a statically significant difference noticed in tuberculous as compared to malignant and postpneumonic origin and transudative pleural effusion.

Conclusion: We concluded that IL-6, IFN- $\gamma$ and ADA levels in pleural effusion are sensitive parameters to differentiate an exudate from a transudate and they can also differentiate exudates of different aetiology. Finally, the results suggest that there is a remarkable difference in production of these three markers in exudative pleural effusions as compared to transudative pleural effusions.
\end{abstract}

Keywords: Adenosine deaminase, gamma interferon, interleukin-6, markers, pleural effusion

\section{Papel de la Interleucina-6, el Interferón Gamma, y la Adenosina Desaminasa como Marcadores en el Tratamiento de Pacientes con Derrame Pleural}

\author{
MAM Marie ${ }^{1}$, J John $^{2 *}$, L Gowda Krishnappa ${ }^{1 *}$, S Gopalkrishnan ${ }^{3}$, SR Bindurani ${ }^{4}$, P CS ${ }^{1}$
}

\begin{abstract}
RESUMEN
Objetivo: El derrame pleural es un problema diagnóstico y clínico común. Las neoplasias y la tuberculosis son las causas más frecuentes en los diagnósticos de tales derrames. Los métodos de laboratorio convencionales para el diagnóstico de tales derrames son ineficientes, porque los bacilos de la tuberculosis raramente se ven en los exámenes directos del líquido pleural. El presente estudio evalúa la interleucina-6, el interferón gamma (IFN- $\gamma$ ) y la adenosina desaminasa (ADA) como herramientas de diagnóstico en el derrame pleural.

Métodos: La interleucina-6, el IFN- $\gamma$, y la ADA fueron medidos en el líquido pleural de los pacientes con derrame pleural exudativo de origen tuberculoso, maligno y post-pneumónico, y el derrame pleural trasudativo de origen sistémico, con el fin de evaluar la utilidad diagnóstica de éstos.

Resultados: Los tres marcadores eran observables en todos los derrames, con niveles significativamente altos en los exudativos en comparación con los trasudativos. Se notó una diferencia estadísticamente significativa en los derrames de origen tuberculoso en comparación con los de origen maligno y postpneumónico, y los derrames pleurales trasudativos.
\end{abstract}

From: ${ }^{1}$ College of Applied Medical Sciences, Clinical Laboratory Department, King Saud University, Riyadh, Kingdom of Saudi Arabia, ${ }^{2}$ Department of Clinical Microbiology, Christian Medical College and Hospital, Vellore, Tamil Nadu, India, ${ }^{3}$ Periyar University, Salem, India and ${ }^{4}$ Department of Microbiology and Biochemistry, Shanthidhama College of Nursing Sciences, Bangalore, India.
Correspondence: Dr M Marie, College of Applied Medical Sciences, Clinical Laboratory Department, King Saud University, PO Box 10219, Riyadh 11433, Kingdom of Saudi Arabia. E-mail: drmmarie.2000@ gmail.com

*Equally contributed to the manuscript 
Conclusión: Llegamos a la conclusión de que los niveles de IL-6, IFN- $\gamma$ y ADA en el derrame pleural, son parámetros sensibles para diferenciar un derrame pleural exudado de uno trasudado, pudiendo por otra parte ayudar también a distinguir exudados de diferentes etiologías. Finalmente, los resultados sugieren que existe una diferencia notable en la forma en que se producen estos tres marcadores en los derrames efusiones pleurales exudativos en comparación con los derrames pleurales trasudativos.

Palabras claves: Adenosina desaminasa, interferón gamma, interleucina-6, marcadores, derrame pleural

West Indian Med J 2013; 62 (9): 804

\section{INTRODUCTION}

Pleural effusion is a common diagnostic problem and may be caused by systemic or local diseases (1). The failure to establish a cause for pleural disease is a frequent problem faced during clinical diagnosis. Pleural effusion can occur as a complication of many different diseases. The most frequent diagnostic causes of such effusions are neoplasms and tuberculosis (2), and frequency of one over another depends upon the population of patients studied.

Tuberculous pleural effusion shows nonspecific clinical presentation and the paucibacillary nature presents a diagnostic challenge. Conventional laboratory methods to diagnose such effusions are not very effective because tubercle bacilli are rarely seen in direct examinations of pleural fluid, and biopsy specimens and cultures are positive in less than $50 \%$ (3). Malignant pleural effusions are mostly caused due to direct invasion of the pleura by malignant cells, or by the presence of a local mediastinal tumour causing bronchial obstruction (4) and can be diagnosed only by demonstrating malignant cells in pleural fluid or pleural tissue. Biological markers have been proposed to establish a cause of pleural effusion. Among all markers, interleukin-6 (IL-6), gamma interferon (IFN- $\gamma$ ) and adenosine deaminase (ADA) were found to have significant roles in such effusion.

Interleukin- 6 is considered as a marker of immune response to any inflammation which regulates cellular immune responses (5). The level of IL-6 was significantly higher in tuberculous effusion than other effusions (6), suggesting that it is produced locally in the pleural space. Gamma interferon is a glycoprotein, produced mainly by natural killer cells and T-helper 1 cells in response to IL-2. Pleural interferon (IFN- $\gamma$ ) levels are also valuable in the diagnosis of pleural tuberculosis, even among different patient subgroups (7). Adenosine deaminase is responsible for lymphocyte differentiation and proliferation and shows significant increased value during immunological response of lymphocytes (8). Investigators have stated that pleural ADA activity is increased in tuberculous pleural effusions and have proposed the usefulness of pleural ADA in the discrimination of tuberculous and non-tuberculous pleural effusions $(9,10)$. It was found that IFN- $\gamma$ and ADA are significantly higher in tuberculous pleural effusion than in other types of pleural effusions (11).

The aim of the present study was to establish if there is a difference among pleural effusion groups: malignant, parapneumonic and tuberculous, and to provide a diagnostic guide based on markers: IL-6, IFN- $\gamma$ and ADA.

\section{SUBJECTS AND METHODS}

A total of 81 pleural fluid samples were collected prospectively from 81 consecutive patients with pleural effusion at Clinics of the Chest Department of el Iman Hospital, Riyadh. The protocol was approved by the hospital ethics committee, and consent was obtained from all subjects for the study. A full research sheet was prepared with complete clinical examination.

Every patient was subjected to plain chest X-ray and electrocardiogram (ECG) and sputum smears were examined by Ziehl-Neelsen stain. Pleural fluid was aspirated from every patient by thoracocentesis (performed under complete aseptic conditions); a part of the specimen was subjected to routine chemical analysis: $\mathrm{pH}$, specific gravity, protein and glucose contents and Ziehl-Neelsen stained smear for detection of tubercle bacilli. A second sample was added to a tube containing ethylenediaminetetraacetic-potassium anticoagulant for total and differential cell counting. Bacterial cultures and cytological examinations were performed on all pleural effusions.

\section{Diagnostic criteria for pleural effusions}

The causative aetiology of the effusion was determined based on the clinical presentation and results of diagnostic test. Effusions were classified into the three groups based on defined criteria.

1) Malignant pleural effusion - diagnosed when malignant cells were detected on cytological examination of the pleural fluid or biopsy specimens, or histologically (with the exclusion of any other cause of pleural effusion).

2) Tuberculosis pleural effusion - diagnosed with positive staining or culture for Mycobacterium tuberculosis in the pleural fluid, sputum or pleural biopsy specimen.

3) Post-pneumonic pleural effusion - a pleural effusion was considered post-pneumonic with symptoms of acute febrile illness, with purulent sputum and pulmonary infiltrates, in the absence of malignancy or other diseases causing an exudate and neutrophilia in the pleural fluid (12).

For cytokine assays - for the cytokine measurement, pleural fluid was immediately centrifuged and kept at $30{ }^{\circ} \mathrm{C}$ until the final procedure (12). 
Value of IL-6 was measured by an enzyme linked immunosorbent assay (ELISA) kit (supplied by CYT ELISA, SYT IMMUNE Science Inc., Maryland, USA) according to the manufacturer's instructions. Gamma interferon was measured by an ELISA kit (supplied by Quantikine kits R\&D system) according to the manufacturer's instructions. Determination of ADA activity was done as described earlier (13).

\section{Statistical analysis}

Group data values are expressed as mean \pm SD. Statistical differences among groups were tested by Student's $t$-test. Correlation analysis was performed using Spearman's coefficients. $P$-value less than 0.05 was considered statistically significant.

\section{RESULTS}

We studied 81 patients with a definite diagnosis and classified them into four groups:

Group I: 38 patients with tuberculous pleural effusion Group II: 11 patients with malignant pleural effusion Group III: 14 patients with post-pneumonic pleural effusion

Group IV: 18 patients with transudative pleural effusion (secondary to heart failure and renal failure)

Table 1 shows the value of parameters in all the conditions. There was no significant difference in $\mathrm{pH}$, specific gravity, protein and glucose contents of the fluid among the different disease conditions. But total leukocyte count was significantly higher in post-pneumonic pleural effusion com- pared to others. Differential count in tuberculous pleural effusion showed elevated lymphocyte and decreased polymorphs. This was not the same as in the other causes of pleural effusion.

\section{Comparison of various types of exudates}

For every parameters tested (Table 2), the pleural fluid levels were slightly higher in exudative than in transudative pleural effusions $(p<0.005)$.

Pleural fluid IL-6 levels were significantly higher in the tuberculous than in the malignant $(\mathrm{p}<0.001)$ and postpneumonic $(p<0.01)$ pleural effusions. There was no significant difference in pleural fluid values of IL-6 levels between malignant and post-pneumonic pleural effusion.

The level of IFN- $\gamma$ in patients with tuberculous effusions was significantly high in comparison with malignant effusions, post-pneumonic effusions and transudative effusions. No statistical difference was found in the mean value of IFN- $\gamma$ in malignant effusions $(93 \pm 35.3 \mathrm{pg} / \mathrm{mL})$ in comparison with post-pneumonic effusions $(108 \pm 34.48$ $\mathrm{pg} / \mathrm{mL})$ and transudative effusions $(80 \pm 25.6 \mathrm{pg} / \mathrm{mL})$.

The mean value of ADA activity in the pleural fluid of patients with tuberculous effusions was statistically significantly different compared to malignant effusions, transudative effusions or post-pneumonic effusions. Also, pleural fluid ADA activity in patients with malignant effusions and post-pneumonic effusion was statistically significantly higher compared to transudative effusions (Table 2).

Table 1: Comparison of chemical analysis of pleural fluid in different pleural effusion

\begin{tabular}{|c|c|c|c|c|c|}
\hline Test & & $\begin{array}{l}\text { Tuberculous } \\
\text { pleural effusion }\end{array}$ & $\begin{array}{l}\text { Malignant } \\
\text { pleural } \\
\text { effusion }\end{array}$ & $\begin{array}{l}\text { Transudate } \\
\text { pleural effusion }\end{array}$ & $\begin{array}{l}\text { Post-pneumonic } \\
\text { pleural effusion }\end{array}$ \\
\hline \multirow{5}{*}{$\begin{array}{l}\text { Specific gravity } \\
\text { pH } \\
\text { Leukocyte count }\end{array}$} & & $1018-1026$ & $1015-1022$ & $1011-1015$ & $1020-1029$ \\
\hline & & $6.9-7.4$ & $7-7.8$ & $7.1-7.4$ & $6.9-7.1$ \\
\hline & - Total & $780-2500$ & $720-1130$ & $80-310$ & $11200-19500$ \\
\hline & - Seg. \% & $20 \%-45 \%$ & $55 \%-90 \%$ & $60 \%-83 \%$ & $62 \%-84 \%$ \\
\hline & - Lymph,\% & $55 \%-80 \%$ & $10 \%-45 \%$ & $17 \%-40 \%$ & $9 \%-14 \%$ \\
\hline \multicolumn{2}{|l|}{ Glucose $(\mathrm{mg} / \mathrm{dL})$} & $45-79$ & $43-90$ & $48-100$ & $25-36$ \\
\hline \multicolumn{2}{|l|}{ Protein $(\mathrm{gm} / \mathrm{dL})$} & $3.2-6.6$ & $3.5-6.1$ & $1.8-2.8$ & $4.6-7.3$ \\
\hline
\end{tabular}

Table 2: Pleural fluid values of interleukin-6 (IL-6), gamma interferon (IFN- $\gamma$ ) and adenosine deaminase (ADA) in patients with tuberculous, malignant and post-pneumonic pleural exudates

\begin{tabular}{llll}
\hline Group & IL-6 (mean \pm SD) & IFN- $\boldsymbol{\gamma}($ mean \pm SD) & ADA (mean \pm SD) \\
\hline Tuberculous & $701.93 \pm 248.61$ & $524 \pm 190.12$ & $66.5 \pm 30.48$ \\
${ }^{*} P$-value & $<0.001$ & $<0.005$ & $<0.005$ \\
Malignant & $436.7 \pm 93.12$ & $93 \pm 35.32$ & $18 \pm 9.94$ \\
${ }^{*} P$-value & $<0.001$ & $<0.01$ & $<0.05$ \\
Post-pneumonic & $365.9 \pm 179.23$ & $108 \pm 34.48$ & $21 \pm 8.9$ \\
${ }^{*} P$-value & $<0.01$ & $<0.01$ & $<0.01$ \\
Transudate & $163.3 \pm 87.2$ & $80 \pm 25.6$ & $8 \pm 2.95$ \\
\hline
\end{tabular}

*p-value compared to exudates 


\section{DISCUSSION}

In this present study, we have evaluated the diagnostic role of IL-6, IFN- $\gamma$ and ADA activity in pleural effusions of different causes [exudative effusion of tuberculosis, malignancy and post-pneumonic and transudative effusion secondary to heart failure and renal failure].

Results showed that values of IL-6, IFN- $\gamma$ and ADA were significantly higher in exudative samples when compared to transudative effusions and also showed a considerable difference in IL-6, IFN- $\gamma$ and ADA among tuberculous and malignant effusion, post-pneumonic and transudative effusion, which is similar to a previous study (14).

Significantly high IL-6 level was seen in tuberculous effusion $(701.93 \mathrm{pg} / \mathrm{mL})$ compared with other exudative and transudative effusions. This result is in agreement with a previous study which showed that IL-6 levels in tuberculous pleural effusion is a characteristic feature of infectious or inflammatory reactions, suggesting that it is locally produced in the pleural space (15). Another study reported low IL-6 levels in transudative and malignant effusions, with high levels in tuberculosis, which is concordant with our study $(16,17)$. These pro-inflammatory cytokines are closely related and may occur in infection. In contrast to our results, high IL-6 levels were detected in pleural effusion of patients with diffuse malignant mesothelioma (17). This discrepancy might be due to the use of different detection methods or differences in the sample size (18).

With regard to IFN- $\gamma$, the highest level was detected in tuberculous effusion and this was significantly high compared with other exudative and transudative effusions. The presence of high values of IFN- $\gamma$ in tuberculous pleural effusion has been documented previously (19) and indicated that IFN- $\gamma$ levels in tuberculous pleural effusion were variable, but non-tuberculous effusions showed lower values. This supports the view that estimation of IFN- $\gamma$ can be a very useful parameter for the diagnosis of tuberculous effusion.

The present study showed that IFN- $\gamma$ was significantly higher in tuberculous effusions than in malignant effusions and the test for measuring IFN- $\gamma$ levels is an excellent method for differentiating tuberculous and malignant effusions and could serve as a more specific test for differentiation $(2,11,12)$. Our results are in accordance with these studies; those patients with tuberculous effusions presented with significantly higher ADA activity compared to patients with non-tuberculous effusions or malignant effusions (20).

On comparing the three types of exudates, IL-6, IFN- $\gamma$ and ADA activity levels were significantly higher in tuberculous than in post-pneumonic pleural fluid, and significantly higher in post-pneumonic when compared to malignant exudates, similar to results obtained by Xirouchaki et al (12). Although the results of the present study suggest that the activity of IL-6, IFN- $\gamma$ and ADA is lower in malignant compared to tuberculous pleural effusions, the final diagnosis of a malignant effusion should still be based on positive cytological and/or histological examination. Tuberculous pleural effusion should be diagnosed based on a positive Ziehl-Neelsen stain, positive culture finding for mycobacteria, and/or pleural biopsy showing typical granulomas. Interleukin-6, IFN- $\gamma$ and ADA activity was found to be higher in the pleural fluid of patients with exudates compared to those with transudates (12).

Like Xirouchaki et al (12), this study showed that the mean levels of all three measured parameters were considerably high in the pleural fluid of patients with exudates than in those with transudates; this could have significant clinical utility in distinguishing transudates from exudates. Further studies on a larger patient population are needed to verify this observation. The significant differences of levels between malignant and post-pneumonic versus tuberculous levels reproduce its applicability for the diagnosis of tuberculous from other causes of effusions and could be useful as a complementary marker.

\section{ACKNOWLEDGEMENTS}

The authors would like to extend their sincere appreciation to the Deanship of Scientific Research at King Saud University for its funding of this research through the Research Group Project no. RGP-VPP-314. The authors certify that there is no conflict of interest with any financial organization regarding the material discussed in the manuscript.

\section{REFERENCES}

1. Ukale V, Agrenius V, Widström O, Hassan A, Hillerdal G. Inflammatory parameters after pleurodesis in recurrent malignant pleural effusions and their predictive value. Respir Med 2004; 98: 1166-72.

2. Aoe K, Hiraki A, Murakami T, Eda R, Maeda T, Sugi K et al. Diagnostic significance of interferon-gamma in tuberculous pleural effusions. Chest 2003; 123: 740-4.

3. Kumar P, Sen MK, Chauhan DS, Katoch VM, Singh S, Prasad HK. Assessment of the N-PCR assay in diagnosis of pleural tuberculosis: detection of $\mathrm{M}$. tuberculosis in pleural fluid and sputum collected in tandem. PLoS One 2010; 5: e10220.

4. Muduly D, Deo S, Subi T, Kallianpur A, Shukla N. An update in the management of malignant pleural effusion. Indian J Palliat Care 2011; 17: 98-103.

5. Daniil ZD, Zintzaras E, Kiropoulos T, Papaioannou AI, Koutsokera A, Kastanis A et al. Discrimination of exudative pleural effusions based on multiple biological parameters. Eur Respir J 2007; 30: 957-64.

6. Wong CF, Yew WW, Leung SK, Chan CY, Hui M, Au-Yeang C et al. Assay of pleural fluid interleukin-6, tumour necrosis factor-alpha and interferon-gamma in the diagnosis and outcome correlation of tuberculous effusion. Respir Med 2003; 97: 1289-95.

7. Villena V, López-Encuentra A, Pozo F, Echave-Sustaeta J, Ortuño-deSolo B, Estenoz-Alfaro J et al. Interferon gamma levels in pleural fluid for the diagnosis of tuberculosis. Am J Med 2003; 115: 365-70.

8. Mishra OP, Ghosh J, Ali Z, Sen M, Prasad R. Lymphocyte adenosine deaminase activity in children with idiopathic nephrotic syndrome. Pediatr Nephrol 2005; 20: 1426-9.

9. Gupta BK, Bharat V, Bandyopadhyay D. Role of adenosine deaminase estimation in differentiation of tuberculous and non-tuberculous exudative pleural effusions. J Clin Med Res 2010; 2: 79-84.

10. Baba K, Hoosen AA, Langeland N, Dyrhol-Riise AM. Adenosine deaminase activity is a sensitive marker for the diagnosis of tuberculous pleuritis in patients with very low CD4 counts. PLoS One 2008; 3: e2788. 
11. Krenke R, Korczyński P. Use of pleural fluid levels of adenosine deaminase and interferon gamma in the diagnosis of tuberculous pleuritis. Curr Opin Pulm Med 2010; 16: 367-75.

12. Xirouchaki N, Tzanakis N, Bouros D, Kyriakou D, Karkavitsas N, Alexandrakis $\mathrm{M}$ et al. Diagnostic value of interleukin- $1 \alpha$, interleukin6 , and tumor necrosis factor in pleural effusions. Chest 2002; 121: 81520.

13. Pérez-Rodriguez E, Jiménez Castro D. The use of adenosine deaminase and adenosine deaminase isoenzymes in the diagnosis of tuberculous pleuritis. Curr Opin Pulm Med 2000; 6: 259-66.

14. Chen M-L, Yu W-C, Lam C-W, Au K-M, Kong F-Y, Chan AY-W. Diagnostic value of pleural fluid adenosine deaminase activity in tuberculous pleurisy. Clinica Chimica Acta 2004; 341: 101-7.

15. Alemán M, de la Barrera SS, Schierloh PL, Alves L, Yokobori N, Baldini $\mathrm{M}$ et al. In tuberculous pleural effusions, activated neutrophils undergo apoptosis and acquire a dendritic cell-like phenotype. J Infect Dis 2005; 192: 399-409.
16. Yenisey C, Aktogu S, Kalenci S, Erer FO. Proinflammatory cytokines: are they useful in differential diagnosis of pleural effusions? Ege Tip Dergisi 2006; 45: 19-24.

17. Monti G, Jaurand MC, Monnet I, Chretien P, Saint-Etienne L, Zeng L et al. Interapleural production of interleukin 6 during mesothelioma and its moduration by $\gamma$-interferon treatment. Cancer Res 1994; 54: 4419 23.

18. ElGendy AM, Abbas Helmy WH, Ezz-ElArab A. Flowcytometric immunophenotyping of peripheral-blood leukocytes in relation to immunopathology and cellular proliferation of pleural mesothelioma. Egypt J Immunol 2006; 13: 87-98.

19. Burgess LJ, Reuter H, Carstens ME, Taljaard JJF, Doubell AF. The use of adenosine deaminase and interferon-gamma as diagnostic tools for tuberculous pericarditis. Chest 2002; 122: 900-5.

20. Reuter H, Burgess L, van Vuuren W, Doubell A. Diagnosing tuberculous pericarditis. QJM 2006; 99: 827-39. 